\title{
THREE TABLETS FROM THE VICINITY OF EMAR
}

\author{
Gary Beckman \\ Yale University
}

Several years ago I examined seven cuneiform tablets in the possession of a New York City antiquities dealer. Five of these were later published by John Huehnergard. ${ }^{1}$ As a supplement to his work I present here copies and brief treatments ${ }^{2}$ of the remaining tablets (nos. 1 and 2 , below), as well as of an additional piece of similar type now in the possession of a private collector in California (no. 3).

No. 1. Syrian type $38.8 \times 5.8 \times 1.9 \mathrm{~cm}$.

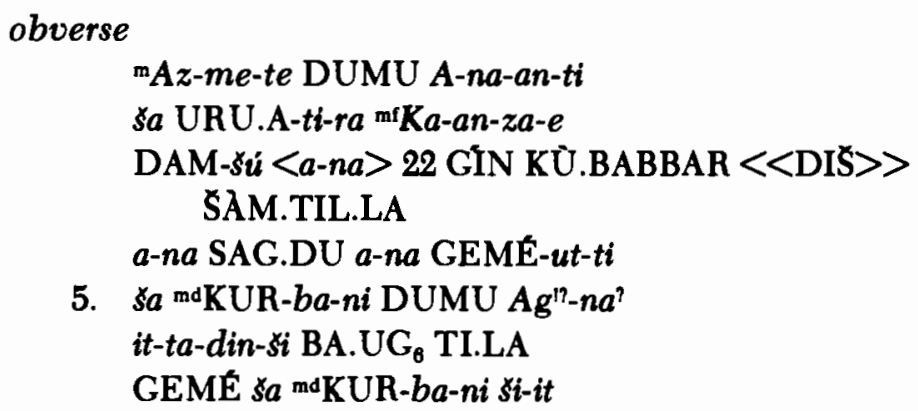

súm-ma i-na EGIR $u_{4}$-mi.MES

1. "Five Tablets from the Vicinity of Emar," RA 77 (1983) 11-43. Other scattered texts of this sort newly published are M. Sigrist, "Miscellanea," JCS 34 (1982) 242-46; J.-W. Meyer and G. Wilhelm, "Eine spätbronzezeitliche Keilschrifturkunde aus Syrien," Damaszener Mitteilungen 1 (1983) 249-61; A. Tsukimoto, "Eine neue Urkunde des Tili-Sarruma, Sohn des Königs von Karkamiš," AcSum 6 (1984) 65-74; and D. Arnaud, "La Syrie du moyen-Euphrate sous le protectorat hittite: L'administration d'apres trois lettres inédites," Aula Orientalis 2 (1984) 179-88. The latter author's edition of the Sumero-Akkadian texts excavated by the Emar expedition is now available: Recherches au pays d'Astata-Emar 6/1-3 (Paris, 1985).

I would like to express my thanks to John Huehnergard and Dominique Beyer, who read earlier drafts of this paper and made many helpful comments, as well as to Maureen Gallery, who brought text no. 3 to my attention. I employ here the abbreviations listed in CHD 3/1 (Chicago, 1980) xxi-xxxi and $3 / 2$ (1983) cover.

2. In particular, prosopographic study is best postponed until the appearance of indices to Emar 6. 


\title{
lower edge
}

ma-am-ma i-bd-qa-ar-si

10. DIS MUNUS.SIG 5 li-din lil-q $e^{\prime}-s i$

\section{$\mathrm{NA}_{4} \cdot \mathrm{KISIB}$}

(seal)

reverse

\author{
IGI' Ma-zi-ya DUMU Zu-bu-ra \\ IGI mKa-ma-lal DUMU Sa-ya-si \\ IGI $m P a-z a-k a$ DUMU Ki-la-e \\ sa URU.A-ti-ra
}

Azmete, son of Ananti, of the town of Atira, has voluntarily sold his wife, Kanzae, into the service of Dagan-bani, son of Agna?, $<$ for $>$ a full price of twenty-two shekels of silver. ${ }^{5}$ Dead or living, ${ }^{6}$ she is ${ }^{7}$ the servant of Dagan-bani.

If in the future someone should redeem her, let him give one healthy woman (in compensation to Dagan-bani), (and) let him take her.

Witnesses: Maziya, son of Zubura; Kamala, son of Sayasi; (and) Pazaka, son of Kilae, (all) of the town of Atira.

The seal impression on this tablet is of a Hittite cylinder featuring the Hittite Storm-god and Sun-god, facing one another across the illegible name of the seal's owner, ${ }^{8}$ as well as the Tutelary Deity armed with a bow

3. On the typology of the Emar texts, see Arnaud, "Catalogue des textes cuneiformes trouvés au cours des trois premières campagnes à Meskéné qadimé Ouest," AAAS 25 (1975) 87-88.

4. For this rendering of ana SAG.DU, cf. Arnaud's translation of the similar $L^{\prime}$ t $u$ SAG.DU, "Humbles et superbes a Emar (Syrie) à la fin de l'age du Bronze récent," in A. Caquot and $M$. Delcor (eds.), Mélanges bibliques et orientaux en l'honneur de M. Henri Cazelles (Neukirchen-Vluyn, 1981) p. 6 with $\mathrm{n} .2$.

5. Line 3 is not entirely in order: First the scribe has omitted the preposition before the numeral, and secondly he has placed a single vertical wedge before SAM.TIL.LA. Although one might read DIS as ana-cf. contemporary texts from Bogazkoy -this would be both unusual for the Emar corpus and syntactically unexpected.

6. For the Sumerographic expression BA.UG ${ }_{6}$ TI.LA in similar contexts, see Emar 6/3 7:7 and $121: 8$.

7. On the use of the Assyrian pronoun sit at Emar, see Huehnergard, RA 77 (1983) 38.

8. This motif is discussed by Beckman, "A Hittite Cylinder Seal in the Yale Babylonian Collection," AnSt 31 (1981) 131-32, 134-35. 
and standing upon an animal, probably a stag. ${ }^{9}$ None of the hieroglyphs are clear enough to be read with certainty.

For the sale of family members by the head of an Emarite household, see Arnaud, Mélanges Cazelles pp. 5-6.

1.

obv.

lower edge

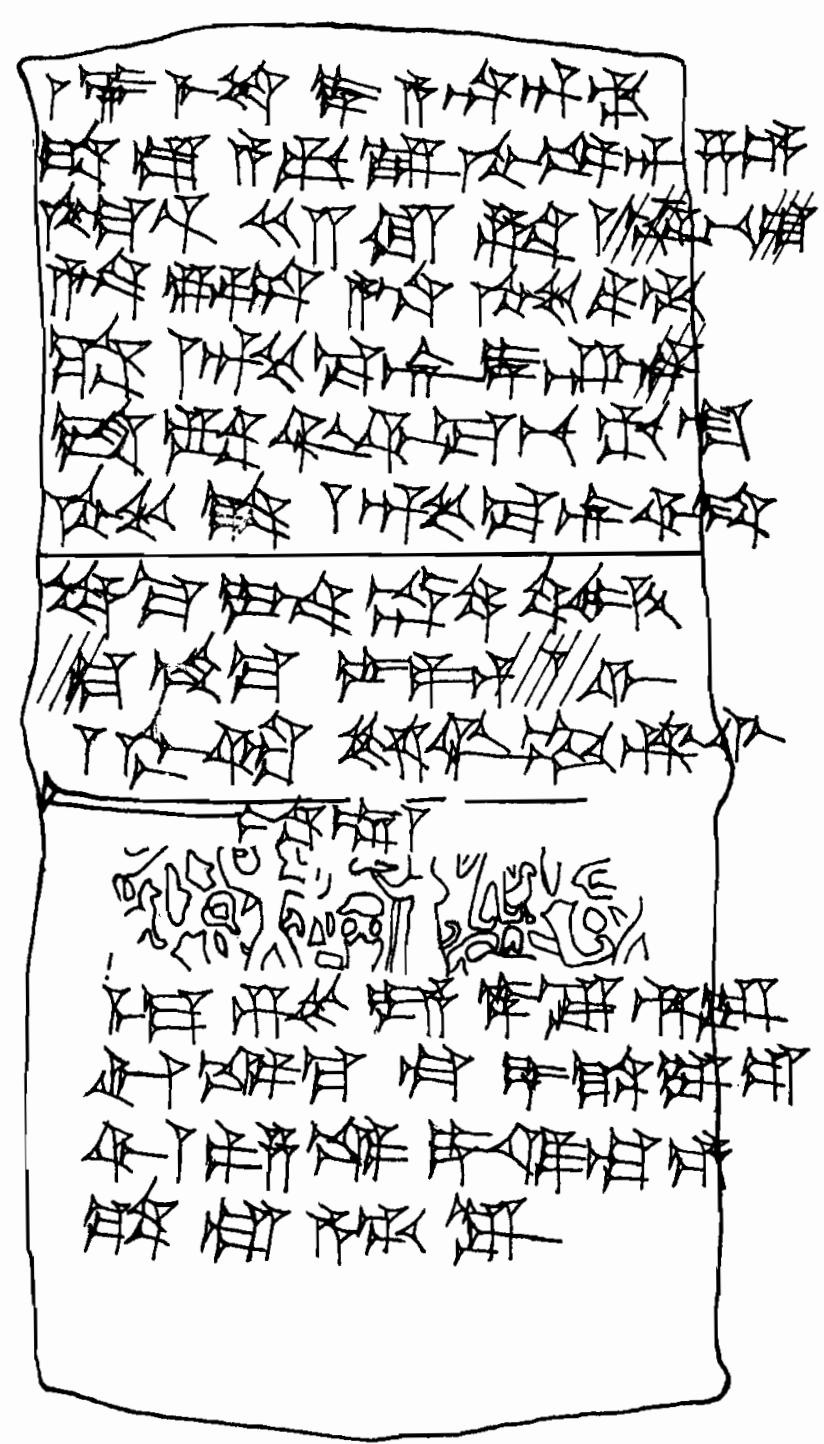

9. C. G. von Brandenstein examines the iconography of this deity in Hethitische Gortter nach Bildbeschreibungen in Keilschrifttexten (Leipzig, 1943) pp. 78-82. 
2.

obv.

rev.

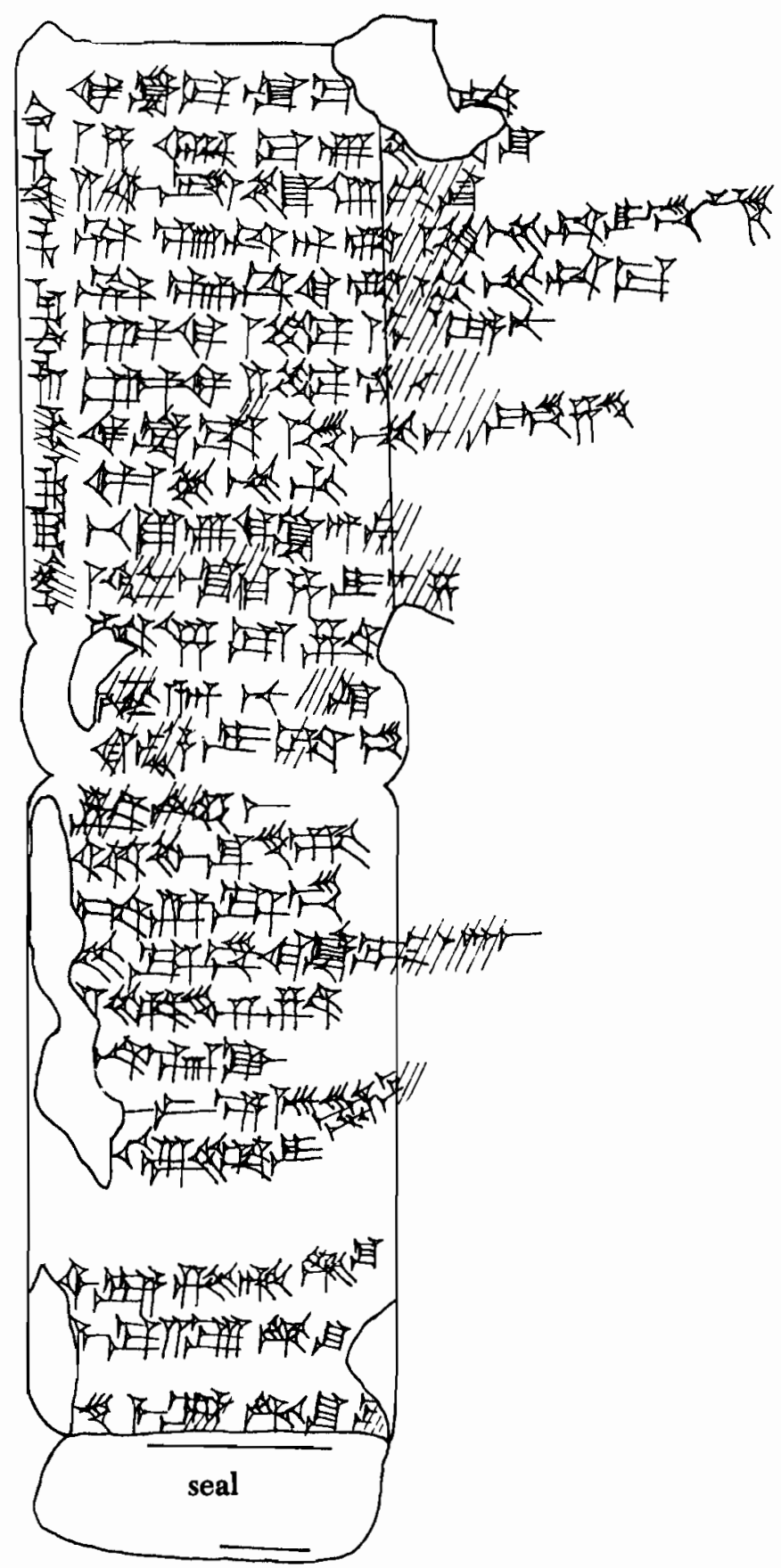


No. 2. Syrian type; $8.0 \times 6.0 \times 2.1 \mathrm{~cm}$.

obverse

KI.KA ma-la ma-[și-ú A]S ÚS?

1 sd-ar-ma-ú G[ID.D]A-šu

2 si-id-dú ru-up-šu

ÚS.SA.DU AN.TA mKam-mu-du DUMU Am-[z]a-bi

5. ÜS.SA.DU KI.TA ${ }^{m} K a m-m u-d u-m a$

SAG.KI.1.KAM-ma ${ }^{\mathrm{m}} M[a]^{\prime}-y a-n u$

SAG.KI.2.KAM-ma KASKAL-nu

KI.KÅ sa ${ }^{\mathrm{m} K a m-m u-d[u}$ D]UMU Am-za-bi

$\mathrm{KI}{ }^{\mathrm{m}} \mathrm{Kam}-\mathrm{mu}-\mathrm{ti}$

10. be-lu-u KI.KA an-ni?

m $E$ b'-la-ku-sd DUMU x-za

$a-n a 15$ GIN KÜ.BABBAR

lower edge

[S]AM.TIL.LA

KI.KA i-sa-am

reverse

15. KÜ.BABBAR mab-rù

SA-bu-su DÜG.GA

sa ur-ra-am

se-ra-am KI.KÁ i-ba-qá-ri

2 li-im KÜ.BABBAR

20. [a-]na E.GAL

I.LA'.E.MES

[IGI] El-li DUMU Pil-s[ú-dKUR]

IGI Ya-st-dKUR SES-su

[I]GI Zu-zu SES'šu

25. [IG]I $\forall i-m e-y a ~ S E S-s u-m[a]$

left edge

IGI Is-dDa-gan LÚ.DUB.SAR

The "place of the gate," as far as it ex[tends i]n expanse ${ }^{10}$ : Its

10. I owe this reading of the end of line 1 to John Huehner gard, who cites the opening of a similar text in private possession: KIRI $\mathrm{H}_{\mathbf{0}}$.NUMUN.MES ma-la ma-sú $i$-na $i$-tá-ti. . . . It should be noted that the well-attested scribe Is-Dagan wrote both tablets, and that the first four witnesses of this unpublished document are identical to those of text no. 2 . 
length is one sarma'u; (its) breadth is two "sides."11 Its upper border is (the property of) Kammudu, son of Amzabi. Its lower border is also (the property of) Kammudu. On one side is (the property of) Mayanu'; on the second side is the road. The "place of the gate" of Kammudu, son of Amzabi, Eblakusa, ${ }^{12}$ son of . . . za, has purchased from Kammudu, the owner ${ }^{13}$ of this "place of the gate," for fifteen shekels of silver, its full price. The silver has been received; his heart is satisfied. Whoever in future should make a claim on the "place of the gate" shall pay two thousand (shekels) of silver to the palace.

Witnesses: (King) Elli, son of Pils[u-Dagan]; Yaşi-Dagan, his brother ${ }^{14}$; Zuzu, his brother; Himeya, also his brother; (and) IšDagan, the scribe.

Although it is certain from context that this tablet records a real estate transaction, the expression KI.K $\AA$ is otherwise unknown to me. ${ }^{15}$ My literal rendering of the Sumerogram is intended only as a temporary expedient. The measure sarma'u, if correctly read, is likewise unattested elsewhere.

11. For siddu as a surface measure, see W. von Soden, AHw $31230 \mathrm{~b}$ (B.5) and compare Emar 6/3 3:2, etc. The writing ru-up-su, without genitive pronoun, is also found in Emar 6/3 $8: 12,19,26$, and elsewhere.

12. Although the individuals are probably not identical, this Hurrian proper name is the same as that appearing elsewhere in Syrian cuneiform material as Ebli-kuša (e.g., Emar 6 12:28 and 144:3) - see E. Laroche, "Les hiéroglyphes de Meskéné-Emar et le style 'SyroHittite'," Akkadica 22 (1981) 11, and Arnaud, Annuaire Ve section (1981-82) 212. A cylinder seal impression bearing this name in hieroglyphs (E-bal-ku-sd) is found on Msk 75.9 (Emar 6 123), a drawing of which is published in D. Beyer (ed.), Meskene-Emar, Dix ans des travaux, 1972-1982 (Paris, 1982) p. 67 fig. 13. [I wish to thank Prof essor Laroche for providing me with a photograph of this impression.] In addition, the metal seal published by me in AnSt 31 (see n. 8 above) belonged to $E$ - $h a-k u-s d$, although there (p. 133) I read the initial sign, L $209=\mathrm{M}$ 171 , inexactly as 1 .

13. The writing be-lu- $u$ in the phrase itti belu $X$ is found, for example, in Emar 6/3 94:9f. (KI PN DUMU PN $_{2}$ be-lu-úki-ir-si-t $\left[u_{4}\right]$ ), and Emar 6/3 138:8f. (KI PN DUMU PN $_{2}$ be-lu- $u$ A.SA.HI.A), as well as in other unpublished Emar-vicinity texts I have studied. See Huehnergard, "Akkadian Evidence for Case-Vowels on Ugaritic Bound Forms," JCS 33 (1981) 199-202, for examples of unexpected vowels in construct forms in Western Peripheral Akkadian, although in most of Huehnergard's data the attested vowel is that appropriate for the grammatical context. Note also $S A-b u$-su in line 18 here.

14. The Sumerogram here, as well as in Huehnergard's text 1 (RA 77 [1983] 14) lines 38 and 39, is clearly SES, not IR. For this shape, see also Emar 6/3 2:32 and 33, as well as passim in this corpus.

15. Pointing out that the scribes of the periphery seem on occasion to have pronounced Sumerograms (note, for example, a-na HA.LI for HA.LA in PRU 6 49:15'), John Huehnergard very tentatively suggests that KI.KA might be an error for $\mathrm{KI} . K A(L)=$ maskanu, "threshing floor; empty lot." He also considers a reading KI.KA-an-ni in line 10. 
The scribe of this text, Is-Dagan, ${ }^{16}$ also wrote the texts published as RA 77 (1983) 14 no. 1 and 16 no. 2. The seal impressed on the upper edge of our text no. 2 is the same as that found on those pieces, but since $I$ have seen this seal on unpublished material from the Emar region produced by other scribes, it is unlikely that this is the impression of the seal of Is-Dagan. ${ }^{17}$

No. 3. Syro-Hittite type ${ }^{18} ; 7.3 \times 5.4 \mathrm{~cm}$.

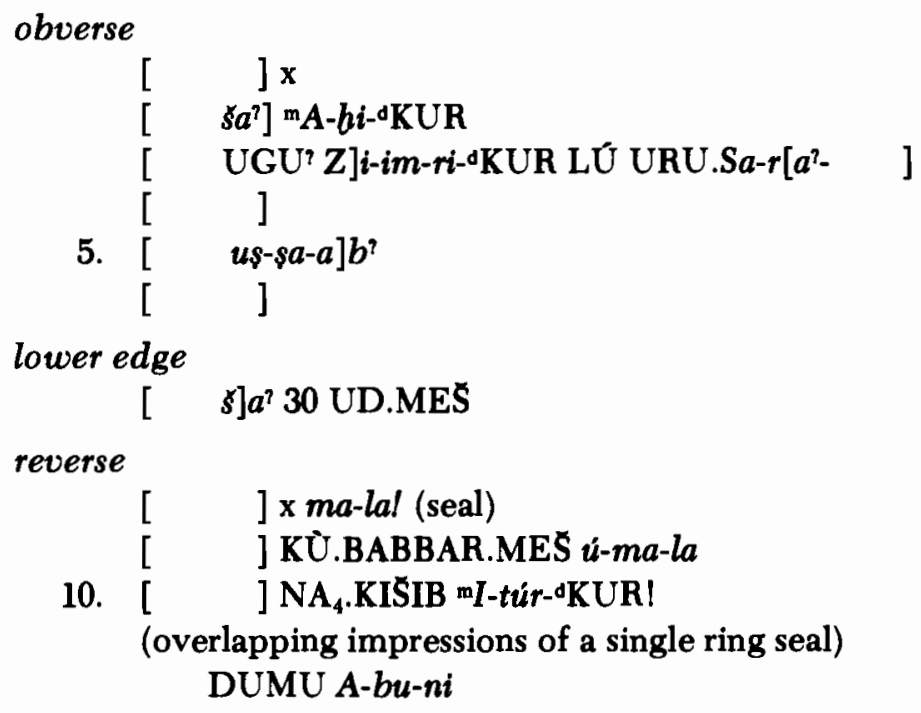

This text is too badly damaged for translation, but line 9 shows that it documents a silver loan: KÜ.BABBAR.MES umalla, "he shall (re-)pay the silver in full." Certainly the most interesting feature of this tablet is the repeated impression of a Hittite ring seal. ${ }^{19}$ This impression-note also the partial impression of a different seal on the upper right of the reverse-

16. See Arnaud, "Les textes d'Emar et la chronologie de la fin du bronze récent," Syria 52 (1975) 90.

17. I suspect that this design, of which I have examined a number of nearly-identical impressions made by at least two different cylinders, is that of the seal of the Emarite royal family. Further study is needed, however.

18. Although inscribed in such a manner that the greatest dimension is horizontal, this piece differs from the usual Syro-Hittite tablet from Emar by its relative thinness, especially near the edges. From its photograph in Beyer, Meskéné-Emar p. 57 fig. 5 (see also Laroche, CRAI [1983] $17 \mathrm{fig} .8$ ), the tablet Msk 73.128 (Emar 6/3 61) seems to be of comparable format.

19. See Güterbock, Boğazköy 573 f. 
bears two names in hieroglyphic script, each marked by the signs L 370-L 386 as male ${ }^{20}$ : on the left I-tu+r-Da-ga, and on the right A-bu-nu. Lines

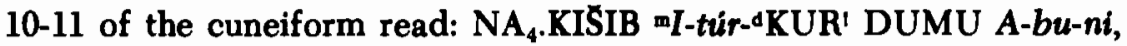
"seal of Itūr-Dagan, son of A buni." Laroche lists the name Abunu/i among those contained in his hieroglyphic material from Emar. ${ }^{21}$

3.

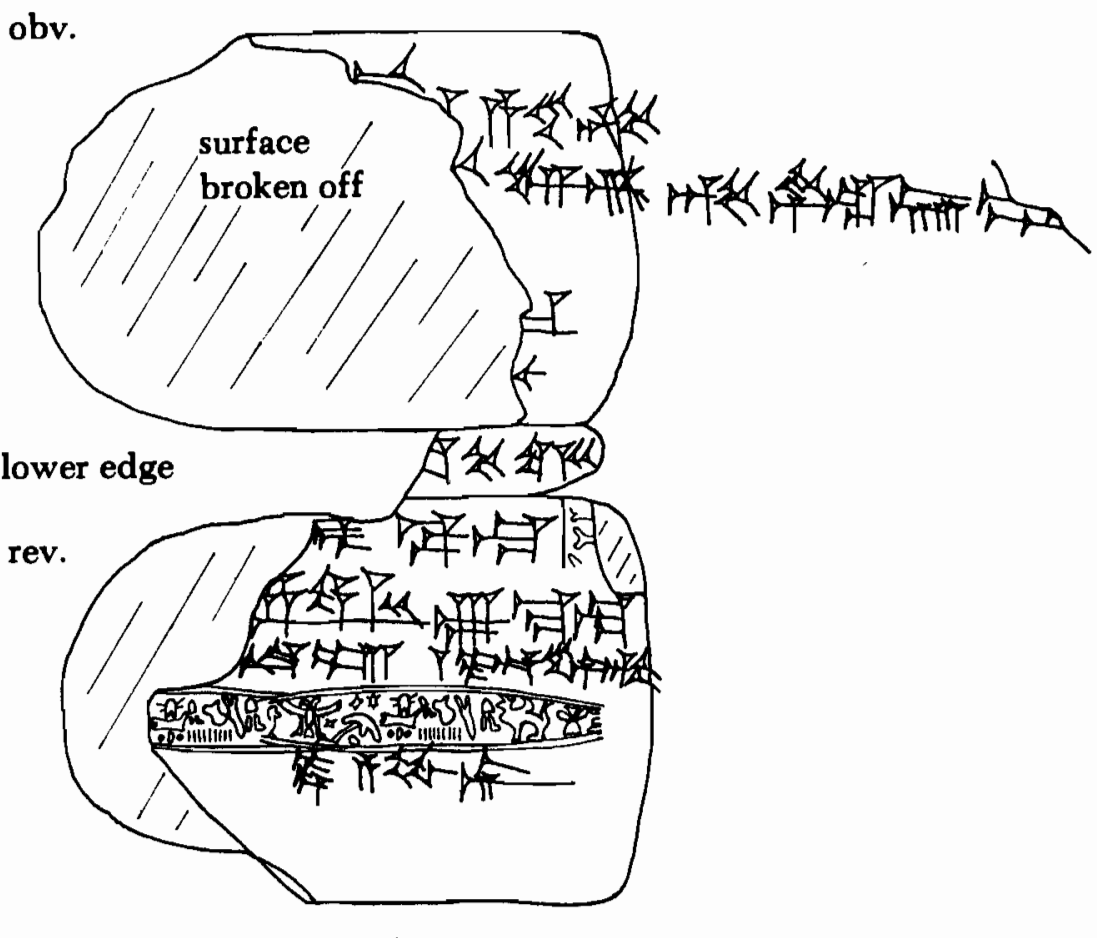

20. Akkadica 22 (1881) 10

21. On this type of glyptic at Emar, see Beyer, Meskéne-Emar p. 68, and Laroche, CRAI (1983) 16. Few examples of Hittite ring seals were available before the discoveries at Meskeneh. For the convenience of the reader I give here a list of those known to me: SBo 2 nos. 222, 225-27, 229-32, 233(?); Boğazkoy 3 pl. 30 no. 36; Boğazkoy 5 p. 55 no. 10, p. 57 no. 15; H. Goldman, Excavations at Golü Kule, Tarsus 2: Plates (Princeton, 1956) pls. 405 no. 16, 408 no. 58; D. Hogarth, Hittite Seals (Oxford, 1920) pl. 7 no. 195 (from Konya?); Ugar. 3 figs 54 and 78; H. Gonnet, Hethitica 6 69-73 (AO 28064, from Ugarit). L. Messerschmidt, CIH pl. 40 no. 1 = D. Kennedy, RHA 65 (1959) 161 no. 41; I. J. Gelb, AnAraş 2 (1965) 225 fig. 8. 